\title{
EFFECT OF VITAMINS K, D AND C SUPPLEMENTATION ON CALCIUM BALANCE AND BONE GROWTH IN YOUNG RATS FED ON A LOW CALCIUM DIET \\ Abdel-Moein, Nadia M. ${ }^{1}$; Mervat S. H Youssef ${ }^{2}$ and K.Y. Farroh ${ }^{2}$ \\ 1 Dept. of Biochemistry, Fac. of Agric., Cairo Univ., Egypt \\ 2 Food and Feed Center Laboratory, Agric. Research Center, Giza, Egypt.
}

\section{ABSTRACT}

The purpose of this study was to clarify the effect of vitamins K, D, and C supplementation on the development of osteopenia in calcium-deficient young female rats. Fourty nine female Sprague-Dawley rats, 6 weeks of age, were randomized into 7 groups with 7 rats in each group: Baseline control, $0.5 \%$ (normal) calcium diet, $0.1 \%$ (low) calcium diet, $0.1 \%$ calcium diet + vitamin K (30 mg / 100g food intake), $0.1 \%$ calcium diet + vitamin D (25 $\mathrm{\mu g} / 100 \mathrm{~g}$ food intake $), 0.1 \%$ calcium diet + vitamin C $(1.5 \mathrm{~g} / 100 \mathrm{~g}$ food intake) and $0.1 \%$ calcium diet $+\mathrm{K}, \mathrm{D}$ and $\mathrm{C}$. After 10 week of feeding, serum calcium, parathyroid hormone (PTH) levels and ALP activity were measured, and intestinal calcium absorption, renal calcium reabsorption, and bone growth parameters were evaluated. Calcium deficiency induced hypocalcemia, increased serum PTH level and ALP activity stimulated intestinal calcium absorption and renal calcium reabsorption and reduced maturation-related bone gain. Vitamin $\mathrm{K}$ supplementation in calcium-deficient rats stimulated elevation of serum PTH level, ALP activity delayed the reduction in femoral bone density and BMD. On the other hand, vitamin $D$ supplementation in calcium -deficient rats stimulated intestinal calcium absorption via increased ALP activity with prevention of the abnormal elevation of serum PTH level, prevented hypocalcemia and retarded the reduction in femoral growth but had no effect on the femoral bone density and BMD.

In contrast, vitamin $C$ supplementation delayed the reduction in femoral bone volume, bone density, and BMD. However, no synthetic effect of vitamin K, D and C on intestinal calcium absorption, renal calcium reabsorption and bone mass was found.

Keywords: Calcium deficiency; Vitamin K; Vitamin D; Vitamin C; Femoral bone growth; Osteopenia; Osteoporosis; Calcium balance.

\section{INTRODUCTION}

Osteoporosis is a systemic skeletal disease characterized by decreased bone mass which results in a markedly increased risk for traumatic fractures. Osteoporosis is a common disease and the incidence is anticipated to rabidly increase because of the aging of the population (Ross, 1998). For example, in the US 25 million people have a lower bone mass and every other postmenopausal woman (> 50 year) is affected by osteoporosis $(\mathrm{NIH}$ Consensus statement, 1995).

Osteoporosis represents a major challenge to the health care services. The annual cost of osteoporosis to the US health care system is estimated to be greater than $\$ 10$ billion (NIH Consensus statement, 1995). The pathogenesis of osteoporosis is multifactorial. Genetic factors, age, gender race, general health, exercise, cigarette smoking as well as nutritional factors are the main parameters which determine the risk for osteoporosis.

Recently, scientists became highly interested in nutrients, which have a potential to minimize the risk to develop osteoporosis (Eaton-Evans, 1994). 
The role of nutrients such as calcium, magnesium protein etc. are widely accepted as part of a strategy to improve bone health (Heaney, 1996).

A bone density increase or stability of bone density is associated with fracture risk reduction calcium and vitamin D deficiency, in approved osteoporosis therapies, while a bone density decrease is cause for clinical concern (MichaelLewiccki, 2003).

It is known that both vitamin $\mathrm{K}$ and vitamin $\mathrm{D}$ affect bone metabolism. In particular, vitamin $\mathrm{D}$ increases intestinal calcium absorption via the action of 1,25 $(\mathrm{OH})_{2}$ vitamin $\mathrm{D}_{3}$ (Baeksgaard et al., 1998 and Shiraishi et al., 1999), while vitamin $\mathrm{K}$ increases renal calcium reabsorption (Kobayashi et al., 2002a). Thus, supplementation of these vitamins may help to increase peak bone mass in adolescent girl. Moreover, because an additive effect of vitamin $\mathrm{K}$ and vitamin $\mathrm{D}$ supplementation on bone mass has been demonstrated in adult ovariectomized rats, young rats and postmenopausal women with osteoporosis (Iwamoto et al., 2000), it would be expected that vitamin $\mathrm{K}$ and vitamin D supplementation might act on bone additively in adolescent girls. However, the effect of vitamin $\mathrm{K}$, vitamin $D$ and vitamin $C$ supplementation on intestinal calcium absorption, renal calcium reabsorption and bone mass growth under calcium deficiency are not clearly understood.

The aims of this study were to clarify the preventive effect of vitamin $\mathrm{K}$, vitamin $D$ and vitamin $C$ supplementation on osteopenia in young female rats under calcium deficiency by nutritional calcium balance study and to determine whether combined supplementation of vitamin $\mathrm{K}$, vitamin $\mathrm{D}$ and vitamin $\mathrm{C}$ would have synergistic effects on the development of osteopenia.

\section{Source of vitamins}

\section{MATERIALS AND METHODS}

Vitamin $\mathrm{K}, \mathrm{D}$ and $\mathrm{C}$, and were purchased from Sigma Chemical Company, Egypt.

\section{Experimental animals}

Animals were female Sprague-Dawley rats, weighing $60 \pm 5 \mathrm{~g}$, 4 weeks of age were obtained from Holding Company of Biological Sera and Vaccines (VACSERA), Cairo, Egypt.

\section{Biological assay}

\section{Treatment of animals:}

Fourty nine female Sprague-Dawley rats were housed in individual metabolic cages. They were fed on a basal diet containing $0.5 \%$ calcium according to Reeves et al. (1993) for two weeks as an adaptation period. After that, the rats, 6 weeks of age, were randomized divided into seven groups of 7 rats in each group: basal control (BLC) group; 0.5\% (normal) calcium diet (NC) group; $0.1 \%$ (low) calcium diet (LC) group; $0.1 \%$ calcium diet + vitamin K (30 mg / $100 \mathrm{~g}$, food intake) (LCK) group; $0.1 \%$ calcium diet + vitamin $\mathrm{D}(25 \mu \mathrm{g} / 100 \mathrm{~g}$, food intake) (LCD) group; $0.1 \%$ calcium diet + vitamin C (1.5 g / $100 \mathrm{~g}$, food intake) (LCC) group; and $0.1 \%$ calcium diet $+\mathrm{K}$ $+\mathrm{D}+\mathrm{C}(\mathrm{LCKDC})$ group.

These special synthetic diets (low calcium + vitamin diets) were formulated by Iwamoto et al. (2004).

The body weight of the rats was weekly recorded and at the end of the experimental period (10 weeks). 


\section{Preparation of specimens:}

The rats in the BLC group were processed for death at 6 weeks of age. One week before sacrifice, food intake was measured, of all rats groups except the BLC group. At the end of the experiment, rats were anesthetized with diethyl ether and blood samples were collected from orbital plexus of all rat groups and allowed to stand at room temperature for $10 \mathrm{~min}$. for blood coagulation, then centrifuged at $4000 \mathrm{rpm}$ for $3 \mathrm{~min}$. The sera were carefully separated and transferred into a sterilized test tube and stored at $-20^{\circ} \mathrm{C}$ until analysis. After that, rats were killed by decapitation and right femur bone was removed. The right femur used for measurements of bone length, wet weight, bone volume (BV), and bone density and was then used for the measurement of bone mineral density (BMD) by dual energy X-ray absorptiometry (DXA).

3. Measurement of serum calcium, phosphorus, creatinine, parathyroid

hormone (PTH) levels and alkaline phosphatase (ALP) activity

The serum calcium, phosphorus and creatinine levels were measured by using Beckman spectrophotometer Model Duß 640 (U.S.A.) according to the method of Burtis et al. (1999). The serum bioactive intact parathyroid hormone (PTH) level was measured according to Jara et al. (1994) using ELISA method. The serum alkaline phosphatase (ALP) activity was measured colorimetrically according to the method of Burtis et al. (1999).

Measurement of femoral length, wet weight, bone volume and bone density

The right femur was dissected free of soft tissue. The length and thickness were measured using a dial caliper according to the method of Iwamoto et al. (2004). Then, the bone was placed in a volumetric flask filled with deionized water. The flask was placed in a desiccator under a vacuum for $2 \mathrm{~h}$. After trapped air had diffused out of the bone, the wet weight of the bone was obtained using a Denver Instrument Company (U.S.A.) balance with a thin wire to which the blotted was attached. The bone was weighed again after submersion in deionized water. The difference between the weight of the bone in air and that in water is bone volume. The wet weight and volume were used for the calculation of bone density according to Iwamoto et al. (2004) method.

\section{Bone density}

Bone mineral density (BMD) of the whole femur was determined by a dual X-ray absorpitometry (DXA) (Model Norland XR-46) according to the method of Iwamoto et al. (2003). The bone were placed in a Petri dish to stimulate soft-tissue density surrounding the bones, tap water was poured around the bones to achieve a depth of $1.0 \mathrm{~cm}$. The results were obtained as bone mineral content and bone area measured. BMD of this are was calculated as bone mineral content divided by bone area.

Determination of intestinal calcium absorption efficiency, calcium balance and calcium retention

Daily calcium intake was determined from food intake, intestinal calcium absorption efficiency, calcium balance and calcium retention were calculated according to Iwamoto et al. (2003) method. 
Statistical analysis:

The statistical analysis was computed using analysis of variance procedure described by Snedecor and Cochran (1980), the significant mean differences between treatment means were separated by Duncan's Multiple Range Test (Duncan, 1955).

\section{RESULTS AND DISCUSSION}

In this study, young female rats were fed on a low calcium diet for studying the effect of vitamin K, D and C supplementation on efficiency of bone formation and calcium homeostasis maintain.

Body weight, femoral length, femoral wet weight, femoral bone volume and bone mineral density (BMD)

Table (1) shows the effect of vitamins K, D and C on body weight, femoral length, wet weight, bone volume, bone density and BMD in rats fed on a low calcium diet. Initial body weight did not significantly differ among the seven groups. Maturation-related body weight gain was reduced in rats of the LC, LCK and LCC groups compared with normal control. Calcium deficiency reduced maturation related in femoral length, wet weight, bone volume, bone density and BMD.

Table 1: Effect of vitamins K, D, and C supplementation on body weight, femoral length, wet weight, bone volume, bone density and bone mineral density (BMD) in rats fed on a low calcium diet

\begin{tabular}{|c|c|c|c|c|c|c|c|}
\hline Group & $\begin{array}{c}\text { Initial } \\
\text { body } \\
\text { weight } \\
\text { (g). }\end{array}$ & $\begin{array}{c}\text { Final } \\
\text { body } \\
\text { weight } \\
\text { (g). }\end{array}$ & $\begin{array}{c}\text { Femoral } \\
\text { length } \\
(\mathrm{mm})\end{array}$ & $\begin{array}{c}\text { Femoral } \\
\text { wet } \\
\text { weight (g). }\end{array}$ & $\begin{array}{c}\text { Femoral } \\
\text { bone } \\
\text { volume } \\
(\mathrm{ml})\end{array}$ & $\begin{array}{l}\text { Femoral } \\
\text { bone } \\
\text { density } \\
\text { (g/ml). }\end{array}$ & $\begin{array}{c}\text { Femoral } \\
\text { BMD } \\
(\mathrm{g} / \mathrm{cm})\end{array}$ \\
\hline BLC & $\begin{array}{c}111.30 \pm \\
1.60^{a}\end{array}$ & - & $\begin{array}{c}23.98 \pm \\
0.17^{\mathrm{c}}\end{array}$ & $\begin{array}{l}0.225 \pm \\
0.005^{\mathrm{e}}\end{array}$ & $\begin{array}{l}0.178 \pm \\
0.004^{\mathrm{e}}\end{array}$ & $\begin{array}{l}1.265 \pm \\
0.002^{d}\end{array}$ & $\begin{array}{c}0.097 \\
0.003^{ \pm}\end{array}$ \\
\hline NC & $\begin{array}{c}106.23 \pm \\
1.41^{\mathrm{a}}\end{array}$ & $\begin{array}{c}210.07 \pm \\
1.588^{a}\end{array}$ & $\begin{array}{c}30.83 \pm \\
0.26^{a}\end{array}$ & $\begin{array}{l}0.581 \pm \\
0.004^{a}\end{array}$ & $\begin{array}{l}0.375 \pm \\
0.002 \text { a }\end{array}$ & $\begin{array}{l}1.548 \pm \\
0.010^{\mathrm{a}}\end{array}$ & $\begin{array}{c}0.181 \\
0.003^{a}\end{array}$ \\
\hline LC & $\begin{array}{c}108.07 \pm \\
1.55^{\mathrm{a}}\end{array}$ & $\begin{array}{c}191.46 \pm \\
1.73^{b}\end{array}$ & $\begin{array}{c}28.90 \pm \\
0.24^{\mathrm{b}}\end{array}$ & $\begin{array}{l}0.359 \pm \\
0.007\end{array}$ & $\begin{array}{l}0.281 \pm \\
0.006\end{array}$ & $\begin{array}{l}1.279 \pm \\
0.004^{\mathrm{cd}}\end{array}$ & $\begin{array}{c}0.105 \\
0.001^{\mathrm{c}}\end{array}$ \\
\hline LCK & $\begin{array}{c}111.27 \pm \\
1.93^{\mathrm{a}}\end{array}$ & $\begin{array}{c}192.63 \pm \\
1.85^{b}\end{array}$ & $\begin{array}{c}29.26 \pm \\
0.23^{b}\end{array}$ & $\begin{array}{l}0.382 \pm \\
0.004^{c}\end{array}$ & $\begin{array}{l}0.291 \pm \\
0.003^{\mathrm{cd}}\end{array}$ & $\begin{array}{l}1.310 \pm \\
0.005^{b}\end{array}$ & $\begin{array}{c}0.114 \\
0.001\end{array}$ \\
\hline LCD & $\begin{array}{c}113.14 \pm \\
1.86^{\mathrm{a}}\end{array}$ & $\begin{array}{c}197.60 \pm \\
2.75^{b}\end{array}$ & $\begin{array}{c}30.56 \pm \\
0.29^{a}\end{array}$ & $\begin{array}{l}0.421 \pm \\
0.004 \mathrm{~b}\end{array}$ & $\begin{array}{l}0.331 \pm \\
0.003^{b}\end{array}$ & $\begin{array}{l}1.271^{ \pm} \\
0.003^{c d}\end{array}$ & $\begin{array}{c}0.105 \pm \\
0.001^{c}\end{array}$ \\
\hline LCC & $\begin{array}{c}109.59 \pm \\
1.24\end{array}$ & $\begin{array}{c}191.04 \pm \\
2.13^{b}\end{array}$ & $\begin{array}{c}28.99 \pm \\
0.28^{b}\end{array}$ & $\begin{array}{l}0.382 \pm \\
0.004^{c}\end{array}$ & $\begin{array}{l}0.296 \pm \\
0.003^{c}\end{array}$ & $\begin{array}{l}1.291 \pm \\
0.006 \mathrm{bc}\end{array}$ & $\begin{array}{l}0.109 \pm \\
0.002 \mathrm{bc}\end{array}$ \\
\hline LCKDC & $\begin{array}{c}109.76 \pm \\
1.71^{\mathrm{a}}\end{array}$ & $\begin{array}{c}196.77 \pm \\
1.94 \mathrm{~b}\end{array}$ & $\begin{array}{r}30.98 \pm \\
0.22^{a}\end{array}$ & $\begin{array}{l}0.422 \pm \\
0.004 \mathrm{~b}\end{array}$ & $\begin{array}{l}0.324 \pm \\
0.002 \mathrm{~b}\end{array}$ & $\begin{array}{l}1.305 \pm \\
0.005^{b}\end{array}$ & $\begin{array}{l}0.110 \pm \\
0.001 \mathrm{bc}\end{array}$ \\
\hline $\begin{array}{l}\text { L.S.D. } \\
(0.01)\end{array}$ & 6.23 & 7.82 & 0.93 & 0.018 & 0.014 & 0.021 & 0.009 \\
\hline
\end{tabular}

- Each value represents the mean \pm S.D.

- Values in the same column with the same letter are not significantly at $(P \leq 0.01)$.

- Whereas: (BLC): Baseline control, (NC): Normal calcium, (LC): Low calcium, (LCK): Low calcium plus vitamin K, (LCD): Low calcium plus vitamin D, (LCC): Low calcium plus vitamin $C$ and (LCKDC): Low calcium plus vitamin $K$, vitamin $D$ and vitamin $C$ as mixture.

Vitamin $\mathrm{K}$ supplementation delayed the reductions in femoral bone density and BMD, whereas vitamin $\mathrm{D}$ supplementation retarded the reductions in femoral length, wet weight, and bone volume, but had no effect on the reductions in femoral bone density and BMD. Vitamin C 
supplementation reduced the reduction in femoral bone volume, bone density and BMD compared with low calcium diet control group. Each significant interaction of vitamin $\mathrm{K}$, vitamin $\mathrm{D}$ and vitamin $\mathrm{C}$ nor a synergistic effect was found in any parameter. These results are harmony with those of Kobayashi et al. (2002b) and Iwamoto et al. (2003).

Serum calcium, phosphorus, creatinine, parathyroid hormone (PTH) levels and alkaline phosphatase (ALP) activity

Table (2) shows the effect of vitamins K, D and C supplementation on the levels of serum calcium, phosphorus, creatinine, PTH levels and ALP activity. Calcium deficiency induced hypocalcemia and increased serum PTH level, resulting in an increase in ALP activity as compared with no calcium deficiency.

Vitamins $\mathrm{K}$ and $\mathrm{C}$ supplementation did not prevent hypocalcemia, but retarded the abnormal elevation of serum PTH level and ALP activity. On the other hand, vitamin $\mathrm{D}$ supplementation prevented hypocalcemia and delayed the abnormal enhancement of serum PTH, creatinine levels and ALP activity compared with calcium-deficient group. A significant interaction and synergistic effect of vitamin $\mathrm{K}$, vitamin $\mathrm{D}$ and vitamin $\mathrm{C}$ were found in the reduction in serum PTH levels and ALP activity.

Table 2: Effect of vitamins $K, D$, and $C$ supplementation on serum calcium, phosphorus creatinine and parathyroid hormone (PTH) levels and alkaline phosphatase (ALP) activity in rats fed on a low calcium diet

\begin{tabular}{|c|c|c|c|c|c|}
\hline Group & $\begin{array}{l}\text { Calcium } \\
\text { (mg/dl) }\end{array}$ & $\begin{array}{l}\text { Phosphorus } \\
\text { (mg/dl) }\end{array}$ & $\begin{array}{l}\text { Creatinine } \\
(\mathrm{mg} / \mathrm{dl})\end{array}$ & $\begin{array}{c}\text { Parathyroid } \\
\text { hormone } \\
(\mathrm{pg} / \mathrm{ml})\end{array}$ & $\begin{array}{c}\text { Alkaline } \\
\text { phosphatase } \\
\text { activity (IU/L) }\end{array}$ \\
\hline$\overline{B L C}$ & $10.15 \pm 0.10^{d}$ & $10.52 \pm 0.08^{c}$ & $0.40 \pm 0.01^{\mathrm{c}}$ & $136.6^{\prime} 2 \pm 3.33^{\mathrm{e}}$ & $96.62 \pm 1.70^{c}$ \\
\hline NC & $10.37 \pm 0.13^{d}$ & $6.69 \pm 0.26^{b}$ & $0.61 \pm 0.02^{a}$ & $137.02 \pm 3.74^{e}$ & $98.98 \pm 2.20^{c}$ \\
\hline LC & $7.76 \pm 0.24^{a}$ & $7.55 \pm 0.26^{a}$ & $0.62 \pm 0.01$ & $405.28 \pm 5.99^{a}$ & $146.81 \pm 2.23^{a}$ \\
\hline LCK & $8.31 \pm 0.25^{a}$ & $7.62 \pm 0.15^{a}$ & $0.62 \pm 0.01$ & $258.01 \pm 3.51^{b}$ & $134.66 \pm 2.70^{b}$ \\
\hline LCD & $9.98 \pm 0.06^{c}$ & $7.70 \pm 0.12^{a}$ & $0.55 \pm 0.00^{b}$ & $170.40 \pm 3.97 d$ & $103.08 \pm 2.97^{c}$ \\
\hline LCC & $9.18 \pm 0.17^{b}$ & $7.60 \pm 0.16^{a}$ & $0.65 \pm 0.01^{b}$ & $208.55 \pm 4.25^{c}$ & $133.57 \pm 2.84^{b}$ \\
\hline LCKDC & $10.22 \pm 0.05^{d}$ & $10.32 \pm 0.19^{c}$ & $0.66 \pm 0.02^{b}$ & $162.82 \pm 4.13^{d}$ & $102.72 \pm 2.54^{c}$ \\
\hline $\begin{array}{l}\text { L.S.D. } \\
(0.01)\end{array}$ & 0.62 & 0.72 & 0.06 & 16.08 & 6 \\
\hline
\end{tabular}

- Each value represents the mean \pm S.D.

- Values in the same column with the same letter are not significantly at $(P \leq 0.01)$.

Generally, it could be considered that the aforementioned vitamins can improve hypocalcemia in calcium deficiency. These data are matching with those Kobayashi et al. (2002a) and Iwamoto et al. (2003) who reported that vitamin $\mathrm{D}$ supplementation in calcium - deficient rats stimulated intestinal calcium absorption via increased serum $1,25(\mathrm{OH}) \mathrm{D}_{3}$ level with prevention of the abnormal elevation of PTH, prevented hypocalcemia. However, no synergistic effect of vitamin $\mathrm{K}$, and vitamin $\mathrm{D}$ on intestinal calcium absorption and renal calcium reabsorption. The incidence of hypocalcemia increased from $15 \%$ to $48 \%$ with corresponding increase in serum PTH values (Slater et al., 2004).

Schaafsma et al. (2001) and Lips (2001) demonstrated that the supplementation of Dutch postmenopausal women with vitamin D $>400$ IU 
led to decrease in serum PTH level. The extracellular fluid concentration is maintained under the influence of 1, 25 dihydroxy D, PTH and calcitonin. Moreover, PTH is also important in the fetus in maintaining the positive calcium balance across the placenta (Wysolmerski and Stewart, 1998).

The optimal serum 25-Hydroxy $D$ level is associated with the maximal suppression of circulating PTH, greatest intestinal calcium absorption, improved bone mineral density, decreased rates of bone loss, decreased risk of falls and ultimately decreased fracture risk (Heaney, 2004).

Vitamin $\mathrm{K}$ delayed abnormal rising of serum parathyroid hormone (PTH) level and reduction in bone gain (Iwamoto et al., 2003). It's improving calcium balance in 20 week old female rats at a dose $31 \mathrm{mg} / \mathrm{kg}$ day by increasing intestinal calcium transport (Kobayashi et al., 2002b and Hara et al., 2002). Allgrove (2003) reported that alkaline phosphatase is required for promote absorption of calcium in the gastrointestinal tract by 1,25 dihydroxy $D$ to aid mineral deposition in bone.

Other studies were preformed by Yamaguchi et al. (2002) showed that vitamin $\mathrm{K}$ caused a significant increase in calcium content and alkaline phosphatase activity in elderly female rat femoral tissues.

Calcium intake, intestinal calcium absorption efficiency, calcium balance and calcium retention:

Table (3) shows the effect of vitamins K, D and C supplementation on the calcium balance in calcium-deficient rats. From the results, calcium deficiency reduced daily calcium intake, stimulated intestinal calcium absorption and renal calcium reabsorption, and increased intestinal calcium absorption efficiency and calcium retention, but decrease calcium balance and induced hypocalcemia.

Table 3: Effect of vitamins K, D, and C supplementation on calcium intake, intestinal calcium absorption calcium absorption efficiency, calcium balance and calcium retention in rats fed on a low calcium diet

\begin{tabular}{|c|c|c|c|c|c|}
\hline Group & $\begin{array}{l}\text { Food intake } \\
\text { (g/day) }\end{array}$ & $\begin{array}{c}\text { Calcium } \\
\text { intake } \\
\text { (mg/day) }\end{array}$ & $\begin{array}{c}\text { Intestinal calcium } \\
\text { absorption } \\
\text { efficiency (\%) }\end{array}$ & $\begin{array}{c}\text { Calcium } \\
\text { balance } \\
(\mathrm{mg} / \mathrm{d})\end{array}$ & $\begin{array}{l}\text { Calcium } \\
\text { retention } \\
(\%)\end{array}$ \\
\hline$\overline{\text { NC }}$ & $13.93 \pm 0.38^{a}$ & $68.95 \pm 1.87^{a}$ & $26.47 \pm 0.64^{d}$ & $16.71 \pm 1.05^{a}$ & $24.19 \pm 0.73^{c}$ \\
\hline LC & $12.67 \pm 0.25^{b}$ & $12.68 \pm 0.25^{b}$ & $79.56 \pm 1.52^{a}$ & $9.75 \pm 0.44^{b}$ & $76.78 \pm 1.54^{a}$ \\
\hline LCK & $12.96 \pm 0.21 a b$ & $12.96 \pm 0.21^{b}$ & $80.35 \pm 0.71^{b}$ & $10.17 \pm 0.26^{b}$ & $78.51 \pm 0.98 a b$ \\
\hline LCD & $13.39 \pm 0.18 \mathrm{ab}$ & $13.41 \pm 0.18^{b}$ & $83.89 \pm 0.83 b c$ & $10.43 \pm 0.25^{b}$ & $77.75 \pm 0.93^{a b}$ \\
\hline LCC & $13.19 \pm 0.17^{a b}$ & $13.20 \pm 0.17^{b}$ & $83.22 \pm 1.26^{b c}$ & $10.75 \pm 0.37^{b}$ & $81.38 \pm 1.52^{b}$ \\
\hline LCKDC & $13.67 \pm 0.30 a b$ & $13.70 \pm 0.30^{b}$ & $84.03 \pm 0.95^{c}$ & $11.04 \pm 0.41^{b}$ & $80.53 \pm 0.96 a b$ \\
\hline $\begin{array}{l}\text { L.S.D. } \\
(0.01)\end{array}$ & 1.02 & 3.13 & 3.16 & 1.65 & 0.00 \\
\hline
\end{tabular}

- Each value represents the mean \pm S.D.

- Values in the same column with the same letter are not significantly at $(P \leq 0.01)$.

Vitamin $\mathrm{K}$ and vitamin $\mathrm{C}$ supplementation stimulated renal calcium reabsorption and increased calcium balance and calcium-retention, but did not influence intestinal calcium absorption efficiency. On the other side, vitamin D supplementation stimulated food (calcium) intake and increased calcium absorption and subsequently, intestinal calcium absorption efficiency, calcium balance, and calcium retention. A significant interaction of vitamin $\mathrm{K}$, 
vitamin D and vitamin C was found in the alteration in renal calcium reabsorption, but no synergistic effect was found.

Very few studies have showed the effects of vitamin $\mathrm{K}$ supplementation on calcium intake, intestinal and renal calcium excretion in calcium deficient animals. In particular, Robert et al. (1985) showed that vitamin K supplementation corrected hypocalciurine in vitamin $\mathrm{K}$ deficient rats. From these finding, the main effect of vitamin $\mathrm{K}$ supplementation in calciumdeficient rat, is considered to be stimulation of renal calcium reabsorption and subsequent retardation of the increase in serum PTH level despite no significant effect on hypocalcemia.

Weber (1999) decided that vitamin D improves bone strength mainly by increasing intestinal calcium absorption and reabsorption of calcium by the kidneys. On the other hand, several intervention studies in human demonstrated that vitamin $\mathrm{D}$ can improve bone status measured by bone density. Vitamin $\mathrm{C}$ is considered as an essential cofactor of collagen formation. Thus, there is a positive association between vitamin $\mathrm{C}$ intake and bone density. The classical function of vitamin $\mathrm{K}$ is required for biological activity of several coagulation factors. A recent research also points to the role of vitamin $\mathrm{K}$ in bone metabolism. So, vitamin $\mathrm{K}$ mediates the carboxylation of glutamyl residues on several bone proteins, notably osteocalcin. and may improve bone health.

\section{Conclusion}

Vitamins $D$ and $C$ supplementation stimulates intestinal calcium absorption efficiency and prevents the reduction in maturation-related bone gain by inducing accumulation of calcium and enhanced calcium retention in young rats fed on a low calcium diet. Vitamin $\mathrm{K}$ supplementation stimulates renal calcium reabsorption and retarded the reduction in body mineral density (BMD). Finally, there is growing evidence that vitamins $\mathrm{K}, \mathrm{D}$ and $\mathrm{C}$ intake could exert a beneficial effect on bone health in female as reported by first epidemiological and clinical studies.

\section{REFERENCES}

Allgrove, T. (2003). Disorders of calcium metabolism. Curr. paediatr., 13:529535.

Baeksgaard, L.; Anderson, K.P. and Hyldstrup, L. (1998). Calcium and vitamin $D$ supplementation increases sinal BMD in healthy, postmenopausal women. Osteporos. Int., 8: 225-260.

Burtis, C.A.; Ashwood, E.R. and Saunvders, W.B. (1999). Tietz textbook of clinical chemistry. $3^{\text {rd }}$ edition.

Duncan, D.B. (1955). Multiple ranges and multiple F test. Biometrics.11: 1-42.

Eaton-Evans, J. (1994). Osteoporosis and the role of diet. Brit. J. Biomed. Sci., 51: 358-370.

Hara, K.; Kobayashi, M. and Akiyama, Y. (2002). Vitamin K2 (menatetrenone) inhibits bone loss induced by prednisolone partly through enhancement of bone formation in rats. Bone, 31: 575-581.

Heaney, R.P. (1996). Nutrition and risk for osteoporosis. In: osteoporosis (marcus, R.; Feldman, D.; Kelsey, J., eds.), pp. 483-505. Academic Press, San Diego. 
Heaney, R.P. (2004). Functional indices of vitamin D status and ramifications of vitamin D deficiency. Am. J. Clin. Nutr., 80: 1706S-1709S.

Iwamoto, J.; Takeda, T. and Ichimura, S. (2000). Effect of combined adwinistration of vitamin $\mathrm{D}_{3}$ and vitamin $\mathrm{K} 2$ on bone mineral density of the lumbar spine in postmenopausal women with osteoporosis. J. Orthop. Sci., 5: 546-551.

Iwamoto, J.; Yeh, J.K. and Takeda, T. (2003). Effect of vitamin K2 on cortical and cancellous bones in orchidectomized and /or sciatic neurectomized rats. J. Bone Miner. Res., 18(4): 776-783.

Iwamoto, J.; Yeh, J.K.; Takeda, T. and Sato, Y. (2004). Effects of vitamin D supplementation on calcium balance and bone growth in young rats fed normal or low calcium diet. Horm. Res., 61(6): 293-299.

Jara, A.; Bover, J.; Lavigne, J. and Felsenfed, A. (1994). Comparison of two PTH assays for the rat: the new immunorandimetric and the older competitive binding assay. J. Bone Min. Res., 9 (10): 1629 - 33.

Kobayashi, M.; Hara, k. and Akiyama, Y. (2002a). Effects of vitamin K2 (menatetrenone) on calcium balance in ovariectomized rats. JPn. J. of Pharmacol., 88(1): 55-61.

Kobayashi, M.; Hara, K. and Akiyama, Y. (2002b). Effect of menatetrenone (vitamin $\mathrm{K}_{2}$ ) on bone mineral density and bone strength in $\mathrm{ca} / \mathrm{mg}$ deficient rats. Nippon Yakurigaku Zasshi, 120: 195-204.

Lips, P. (2001). Vitamin D deficiency and secondary hyperparathyroidism in the elderly: consequences for bone loss and fractures and therapeutic implications. Endocrine Rev., 22: 477-501.

Michael-Lewiccki, E. (2003). Non-responders to osteoporosis therapy. J. Clin. Densit., 6 (4): 307-314.

NIH Cosensus Statement (1995). Optimal calcium intake. Nutr., 11: 409-417.

Reeves, P.G.; Nileson, F.H. and Fahey, G.C. (1993). AIN-93 Purified diets for laboratory rodents: final report of the American institute of Nutrition ad hoc writing committee on the reformulation of the AIN - 76 A rodent diet. J. Nutr., 123: $1939-51$.

Robert, D.; Jorgetti, V.; lacour, B.; Leclerq, M.; Cournot-Witnor, G.; Ulmann, A. and Drüeke, T. (1985). Hypercalciuria during experimental vitamin $\mathrm{K}$ deficiency in the rats. Calcif. Tissue Inter., 37: $143-147$.

Ross, P.D. (1998). Osteoporosis: Epidemiology and risk assessment. J. Nutr. Health and Aging, 2: 178-183.

Schaafsma, A.; Muskiet, F.A.; Storm, H.; Hofstede, G.J.; Pakan, I. and Van der Veer, E. (2001). vitamin $D_{3}$ and vitamin $K_{1}$ supplementation of Dutch postmenopausal women with normal and low bone mineral densities: effects on serum 25-hydroxyvitamin $D$ and carboxylated osteocalcin. Eur. J. Clin. Nutr., 55(4): 305-307.

Shiraishi,A.;Higuchi,S.;Ohkawa,H.;Kubodera,N.;Hirasawa,T.;Ezawa,I.;Ikeda, K.and Ogata,E.(1999). The advantage of alfacalcidaol over vitamin D in the treatment of osteoporosis.Calcif.Tissue Int.,65:311-316.

Slater, G.H.; Ren, C.J.; Siegel, N.; Williams, T.; Barr, d.; Wolf, B.; Dolan, K. and Fielding, G.A. (2004). Serum-fat soluble vitamin deficiency and abnormal calcium metabolism after malabsorptive bariatric surgery. J. Gastrointest. Surgery., 8: 48-55. 
Snedecor, G.W. and Cochran, W.G. (1980). Statistical Methods. $7^{\text {th }}$ Ed. lowa State Univ. Press, lowa, USA.

Weber, P. (1999). The role of vitamins in the prevention of osteoporosis-a bif status report. Int. J. vitam. Nutr. Res., 69(3): 194-197.

Wysolmerski, J.J. and Stewart, A.F. (1998). The physiology of parathyroid hormone related peptide: an emerging role as a developmental factor. Ann. Rev. Physiol., 60: 431-460.

Yamaguchi, M.; Uchiyama, S. and Tsukamoto, Y. (2002). Stimulatory effect of menaquinone-7 on bone formation in elderly female rat femoral tissues in vitro: prevention of bone deterioration with aging. Int. J. Mol. Med., 10(6): 729-733.

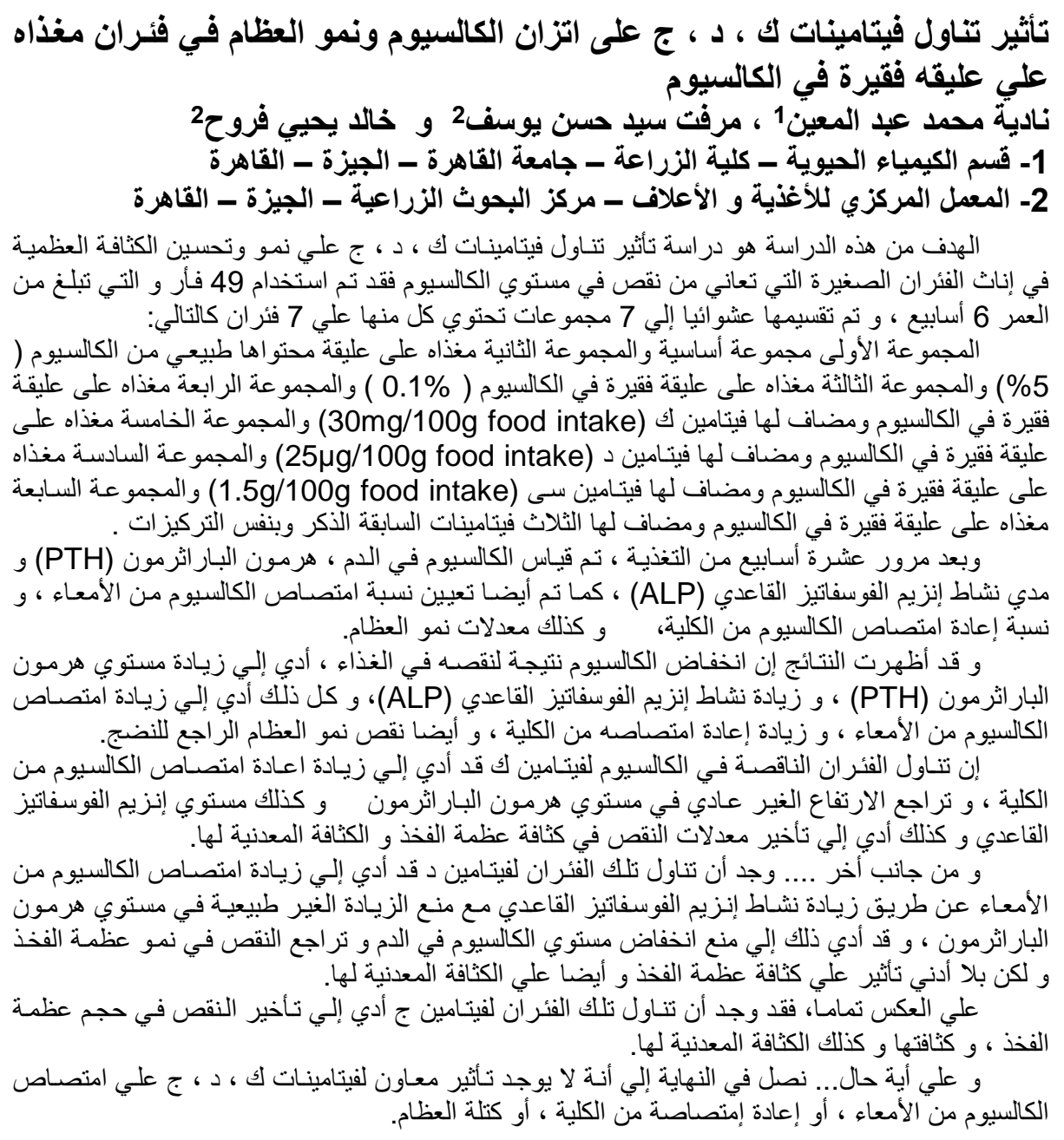


J. Agric. Sci. Mansoura Univ., 33 (3), March, 2008

2505

2506

2507

2508

2509

2510

2511

2512

2513 